\title{
Is there a "universal" model of the president's constitutional responsibility in European countries?
}

Keywords: president, constitutional responsibility, constitution, court, tribunal, parliament

\begin{abstract}
Constitutional responsibility of the president, together with mechanisms of legal constitutional control as well as the control of legality of decisions performed by administrative organs, is a significant instrument, which serves to guarantee the rule of law.

In literature it is indicated that constitutional responsibility possesses an individual character, it relies on fault, whereas the penalties have a particular character. The sole proceeding, in terms of people being held administratively liable, relies on disclosing and determining all circumstances related to committing the constitutional tort and punishment of a person who committed it. The key function of the proceedings is compensation towards justice and strengthening of legality, as well as commencement of actions of preventive dimension towards the people holding important positions within the country.

The author in the article attempted to create a universal model of the constitutional responsibility of the president in European countries.
\end{abstract}

The constitutional responsibility of the president of a state, together with the mechanisms of legal constitutional control as well as the control of the legality of decisions made by administrative bodies, are signifi-

* ORCID ID: https://orcid.org/0000-0003-0530-708X, University of Rzeszow. 
cant instruments, which serve to guarantee the rule of law ${ }^{1}$. B. Banaszak states that constitutional responsibility should be understood as the consequences of the behavior of persons occupying high state functions, in the event of a violation of the constitution or statutes, in connection with their function ${ }^{2}$. The literature indicates that constitutional responsibility is individualized, based on guilt, while penalties are of a specific nature. On the other hand, the procedure itself, in relation to persons held for constitutional responsibility, consists in disclosing and establishing all circumstances related to the committed constitutional tort and punishing the person who committed it. The primary function of these proceedings is to satisfy the sense of justice and strengthen the rule of law, as well as to take preventive measures in relation to persons performing important functions in the state ${ }^{3}$.

The institution of the president's constitutional responsibility is an important element in the constitutional regulations of states with a democratic system, in which no responsibility for violations of the law is allowed. The head of state is protected by immunity, however, it is not complete immunity. In a situation where the president violates the constitution or laws, during and in connection with his position, President has to take into account legal consequences.

Due to the complicated procedure to execute thereof, the institution has currently a preventive role. The rationale for this is two-fold: firstly, the institution of constitutional responsibility of a president does not allow the person holding this position to feel immune from punishment; secondly, paradoxically, thanks to the existence of a legally determined and strongly formalized procedure, the president is protected against attempts to deprive them of the office by other methods. This is fairly similar to parliamentary responsibility.

In current legal regulations in the European countries, four models of presidential constitutional responsibility can be distinguished. The element determining the responsibility model is the body, to which the legislator entrusts to adjudicate over the constitutional responsibility of

1 Cf. P. Chrzczonowicz, Problem odpowiedzialności konstytucyjnej i karnej Prezydentów Rzeczypospolitej Polskiej i Republiki Wtoskiej, [in:] Z. Witkowski (ed.), Konstytucjonalizm włoski i polski $w$ aktualnych fazach ich przemian. Materiały z sympozjum. Toruń, 2 czerwca 2005, Torun 2005, pp. 179-180.

2 Cf. B. Banaszak, Porównawcze prawo konstytucyjne wspótczesnych państw demokratycznych, Warszawa 2007, p. 403.

3 Cf. ibidem. 
the president. These bodies are: 1) a special, court-like body, 2) constitutional court, 3) parliament, 4) citizens. However, each of the solutions has drawbacks. Therefore, while analyzing the solutions applied in the case of the institution of the president's constitutional responsibility in European countries, I came to certain conclusions which resulted in the creation of a model that, in my opinion, could be applied in any of the European republics. This study is also devoted to this issue.

There has only been one case in Europe when the president was found guilty of committing a constitutional tort and was removed from office. This was when the President of the Republic of Lithuania Rolandas Paksas was removed from office in 20044. In December 2003, the Sejmas created a special committee of inquiry, the main task of which was to determine if the motion of a group of deputies, concerning the prosecution of the president, was relevant. The claimants stated that the president infringed the Lithuania Constitution and broke his oath. In February 2004, the president issued a written statement before the committee of inquiry. Upon request of the committee, the Sejmas filed a motion to the Constitutional Court to investigate if the president had infringed the Constitution by granting Lithuanian citizenship to J. Borys. Next, a special committee of inquiry unanimously accepted six accusations, against the Lithuanian president and presented them to the Sejmas.

On February 19, 2004, the Sejm, after hearing motions incriminating against R. Paksas, adopted a resolution on prosecuting the president and appointed five accusers. The next parliament asked the Constitutional Court to investigate if the alleged actions of R. Paksas seriously infringe the Constitution and the presidential oath.

On March $31^{\text {st }}$ 2004, the Constitutional Court issued its opinion concerning the conformity of actions of the Lithuania President R. Paksas with the Constitution. The president had not personally participated in any of the sittings of the Constitutional Court, but through his attorneys, he had presented written clarifications. In the opinion the Constitutional Court determined three actions that were non-conformant with the Constitution: the unlawful granting of Lithuanian citizenship in an

4 Cf. M. Giżyńska, Odpowiedzialność konstytucyjna głowy państwa w Republice Litewskiej (na tle kazusu Rolandasa Paksasa), [in:] A. Jamróz, S. Bożyk (eds.), Z zagadnień wspótczesnych spoteczeństw demokratycznych, Białystok 2006, pp. 328-337, D. Górecki, R. Matonis, Odpowiedzialność konstytucyjna Prezydenta Republiki Litewskiej Rolandasa Paksasa, «Przegląd Sejmowy» 2004, No. 4. 
extraordinary procedure to J. Borys, and this was a serious infringement of the Constitution; the conscious transfer of information concerning the investigation of $\mathrm{J}$. Borys directly to him, which is a serious infringement of the Constitution and breach of the oath; and during a privatization process, he acted in person and acted through representatives for the benefit of his relatives, which was determined as serious infringement of the Constitution and breach of the oath.

The trial took place in the Sejmas from April $5^{\text {th }}$ to April $6^{\text {th }} 2004$. The Parliament accused the President of committing actions, which the Constitutional Court recognized as serious infringement of the Constitution. President R. Paksas stated that he had make mistakes, but they did not lead to any damage to Lithuania, and that he had become the victim of the elite's plot, who had utilized dual standards to political manipulation the situation. The Sejmas then voted on the accusations against the president and in all three cases, he was found guilty of dereliction of his presidential duties, and thus the President was dismissed from his position.

Pursuant to the Constitution, the duties of the president until the early elections were performed by the chairman of the Seymas A. Paulauskas, and the function of the chairman of the Seym by the former vice-chairman C. Juršenas.

As far as finding the President guilty of the dereliction of his presidential duties and being removed from his post, there is only one case where there was an attempt to hold a president constitutionally liable. This situation, which may have been an attempt to force a president to admit guilt, took place in Italy in 1978, when president G. Leone was forced to resign due to allegations of corruption and taxation abuse described by the press ${ }^{5}$. G. Leone was attempting when? to introduce constitutional reform to the state, and because of this he had many political enemies. So, it can be assumed that this resignation was a hidden form of dismissal of a president, due to of political infighting ${ }^{6}$.

The only situation when a formal motion to hold the president guilty took place, having been accused of being guilty of a dereliction of constitutional duties, also took place in Italy ${ }^{7}$. In 1991 a group of leftwing

5 I. Bokszczanin, Prezydent Republiki Wtoskiej, [in:] J. Osiński (ed.), Prezydent w państwach wspótczesnych, Warszawa 2009, p. 752.

6 E. Berselli, Tutti poreti del presidente, «Il Mulino» 1992, No. 2, pp. 215-216.

7 S. Grabowska, Udziat parlamentu $w$ postępowaniu $w$ sprawie odpowiedzialności konstytucyjnej Prezydenta Republiki Włoskiej, «Gdańskie Studia Prawnicze» 2014, T. XXXI, pp. 261-268. 
parliamentarians made an attempt to initiate a procedure of accusation against President F. Cossigi ${ }^{8}$. He was accused of "adopting acts and proceeding with the intention of changing the form of government using measures unacceptable to the constitutional order of the state" 9 . The applicants accused F. Cossidze of misusing presidential powers, attempting plebiscite rule and improper cooperation with political parties. However, when F. Cossig resigned in 1992, a parliamentary committee set up in connection with the submission of the application discontinued the case in 1993 as "manifestly unfounded" 10 .

Attempts to hold the president constitutionally liable also took place in Romania ${ }^{11}$. On July $5^{\text {th }} 1994$, the Constitutional Court released an opinion suspending the Romania President I. Iliescu from his official duties ${ }^{12}$. The President was not suspended and the case was closed. Another attempt to remove the President from his position ex-officio took place in $2007^{13}$. The motion to suspend President T. Băsescu from his position was signed by 182 deputies and senators. In 2007, a debate was conducted during a joint sitting of both chambers of the Romanian Parliament. The parliamentarians accused the President of infringing several provisions of the Romanian Constitution. The motion of suspension consisted of six parts, indicating the infringements or categories of the infringements of the Romanian Constitution. However, the elements necessary to classify the allegation as a serious violation of the Romanian Constitution were not indicated in every case $^{14}$.

8 Cf. R. Bin, G. Brunelli, A. Pugiotto, P. Veronesi, Il „Caso Cossiga”. Capo dello Stato che esterna o privato cittadino che offende?, Torino 2003.

9 Z. Witkowski, Ustrój konstytucyjny wspótczesnych Włoch $w$ aktualnej fazie jego przemian 1989-2004, Toruń 2004, p. 229.

10 Cf. M. Fiorillo, Il capo dello stato. La democrazia dalla A alla Z, Roma-Bari 2002, p. 27, K. Witkowska-Chrzczonowicz, Formy odpowiedzialności konstytucyjnej w Republice Wtoch, [in:] S. Grabowska, R. Grabowski (eds.), Formy odpowiedzialności konstytucyjnej w państwach europejskich, Torun 2010, p. 374.

11 Cf. S. Grabowska, R. Grabowski, Odpowiedzialność prawna czy polityczna? Watpliwości w sprawie charakteru instytucji odpowiedzialności Prezydenta Republiki Rumunii, [in:] R.M. Czarny, K. Spryszak (eds.), Państwo i prawo wobec wspótczesnych wyzwań. Wspótczesne ustroje państwowe i rozwój demokracji w Polsce. Ksiegga jubileuszowa Profesora Jerzego Jaskierni, T. II, Toruń 2012, pp. 171-190.

12 W. Sokolewicz, Sąd Konstytucyjny w Rumunii, [in:] J. Trzciński (ed.), Sądy konstytucyjne w Europie. Butgaria, Czechy. Rumunia. Stowacja, Wegry, T. 2, Warszawa 1997, p. 163.

13 Resolution no 4 of February $28^{\text {th }} 2007$ in terms of suspending the Romania president in the performance of his duties (M.Of. No. 151 of March $2^{\text {nd }} 2007$ ).

14 S. Grabowska, Formy odpowiedzialności konstytucyjnej w Republice Rumunii, [in:] S. Grabowska, R. Grabowski (eds.), Formy odpowiedzialności konstytucyjnej w państwach europejskich, Toruń 2010, pp. 260-280. 
The Constitutional Court issued an opinion in which it stated that acts violating the Romanian Constitution and the president's actions taken in the exercise of office, and constitutional responsibility indicated by the applicants, could not be classified as serious violations justifying the suspension of holding the office of the President of Romania ${ }^{15}$. This opinion was presented to the Romania President and the chairmen of both chambers of Parliament. Then proposal to suspend Romanian President T. Băsescu, has been the subject of discussion during a joint meeting of both chambers, after which a vote was taken and a resolution on the suspension of the president's office. Based on the resolution passed by the parliament, the chairman of the Chamber of Deputies B. Olteanu, who chaired the meeting of the combined chambers of parliament, requested the Constitutional Court to state the circumstances justifying the existence of a temporary obstacle to the office of the President of Romania, as a result of which the office of president should become covered by the chairman of the Senate, N. Văcăroiu ${ }^{16}$.

The Constitutional Court determined the circumstances justified the existence of a current obstacle for the president of Romania to hold his position and assessed that according to provisions of article 98 section 1 of the Romanian Constitution, the function of the Romania president was to be taken by the chairman of the Senate, N. Văcăroiu ${ }^{17}$. The resolution of the Constitutional Court was presented to the Parliament and the government. During a joint sitting of both chambers, on April 24th, the parliament ordered a referendum concerning the dismissal of the Romania president from his post ${ }^{18}$. However, when the referendum took place on May 19th 2007 74\% of the electors voted against the Romania president T. Băsescu being suspended from his post ${ }^{19}$.

Just as the model of extra-parliamentary (judicial) control of the constitutionality of law has spread, so should - in my opinion - the model of extra-parliamentary decision-making about constitutional accountability

15 Advisory opinion no 1 of the Constitutional Court of April $5^{\text {th }} 2007$ concerning the suggestion of suspending the Romania president Traiana Băsescu (M. Of. No. 258 of April $18^{\text {th }}$ 2007), p. 8.

16 A letter of the President of the Chamber of Deputies No. 1041/1 B.O. of April 20 th 2007, registered in the Constitutional Court under number 3762.

17 Ibidem.

18 Resolution no 21 of the Parliament of April 24th 2007 in terms of ordering a referendum concerning the dismissal of the Romania president. (M. Of. No. 273 of April 24 $4^{\text {th }} 2007$ ).

19 K. Ryan, A President triumphs at the polls - but is humbled by his loose tongue, «The Economist» of May 26 2007 , p. 28. 
spread, while leaving the right of initiative to politicians - and more specifically - in this respect - to the parliamentary majority.

After getting acquainted with the provisions governing the procedure for holding the president to constitutional responsibility and analyzing them, it is possible to create a "universal" model that can be applied in any country, taking into account such an institution in its legal system ${ }^{20}$. It combines the best features of all currently used solutions, increasing the effectiveness of the procedure and optimizing its effects.

In the proposed model, the right to submit a motion to bring the president to constitutional accountability should be granted not only to a group of parliamentarians (comprising at least a quarter of their total number), but also to the government as a whole and a group of citizens, in the number required to support the people's motion to hold a referendum. The fact that it is this body, which is included in the executive branch alongside the president, has the best knowledge of the actions taken by the head of state, as well as their legality, in favor of granting such a right to the government. On the other hand, allowing citizens to submit a motion regarding the president's constitutional responsibility seems obvious in the context of popularizing the presidential election.

The subject of the proceedings should be a violation of the constitution, but only a serious violation, as Italian regulations define - "an attack on the constitution", as well as a serious violation of laws concerning the state system. Arguments in this respect are provided by the case of R. Paksas, who was accused of breaking the provisions of the constitution by violating the procedure of granting citizenship. The application would be submitted to the chairman of parliament, or to the chairman of one of the chambers of parliament, provided that in a given country we are dealing with a bicameral parliament.

In my proposed model of the "universal" model of constitutional responsibility of the president, the motion would comprise of: an indication of the committed actions, an indication of the legal grounds, a list of provisions infringed by the president and a justification (together with an analysis of the results of the actions and omissions of the president). All the evidence should be attached to the application. I suggest that the

20 In terms of a country which does not have such an institution as a constitutional court (Iceland) the right to adjudicate in terms of constitutional responsibility should be transferred to a judicial body that can adjudicate in cases related to the constitutionality of law. Cf. S. Grabowska, Referendum jako instytucja odpowiedzialności konstytucyjnej prezydenta. Analiza islandzkich regulacji, [in:] J. Ciapała, P. Mijal (eds.), Księga Jubileuszowa prof. Andrzeja Bałabana, Szczecin 2017, pp. 94-102. 
petitioners should indicate the accuser and one deputy in the motion, who would be responsible to issue the statement of objections during the proceedings. Accuser and their deputy would need to be practicing lawyers. This w would professionalize the proceedings and likely minimize the chances of actioning a politically-driven motion? The initiators of the proceedings should file it with the chairman of the parliament (or the chairman of one of the parliamentary chambers).

They should they transfer the motion to a parliamentary sitting (or a joint sitting of both chambers of the parliament). This solution is justified because such serious allegations should be debated - in the first place - by the parliament in pleno, rather than a committee of the parliament.

At the same time as sending the motion to parliament, the chairman of parliament would inform the president about the submission of a motion to bring him to constitutional responsibility for committing a constitutional tort. Along with the information, he would provide the president with a copy of the application along with other documents. Thanks to this, the president would have time to prepare explanations in the matter. It seems necessary to regulate this issue, due to the lack of provisions regulating this stage of proceedings in a number of constitutions and acts of the analyzed states. At this stage, the president has rights - at least identical - to all parties to the proceedings, including the right to be properly notified.

Taking proceedings or refusing to initiate proceedings - given the seriousness of the case - would fall within the competence of the parliament. If the motion had errors or formal shortcomings, the speaker of parliament would have called on the initiators to remedy them within one week of receiving the request. Applicants would have fourteen days to correct or complete them. If the applicants had not remedied the formal errors, the chairman of parliament - after consulting the parliament - would have refused to follow up on the motion.

If the parliament were to initiate a procedure on the president's constitutional responsibility, the motion, along with the parliament's resolution, would be forwarded to the committee, preferably it should be a parliamentary committee with constitutional responsibility. It does not seem justified to establish a special commission or a commission of inquiry which, by definition, serve other purposes. If there is a bicameral parliament in a given country, the committee should be composed of members of both chambers. The duties of the committee would be to examine - on the basis of the materials received - not so much the valid- 
ity, but the probability of the justification of the allegations made in the motion. The committee would produce a report on its work, analyzing the information and documents in its possession.

The committee would also be tasked with appointing a rapporteur from among its members to present the committee's report to the plenary session of parliament, and two prosecutors and two deputy prosecutors who, if parliament endorsed the proposal, would take part in further proceedings. Prosecutors and their deputy would have to, as in the case of persons nominated by the applicants as prosecutor and his deputy, have legal education and practice in this field. The commission would have one month to carry out work related to the motion to bring the president to constitutional responsibility.

Upon completion of its work, the committee would submit a written report to the chairman of parliament who would arrange for a debate on the report within two weeks of its submission. In a bicameral parliament, the debate should be held at a joint session of the chambers, chaired by the chairman of the chamber which received a motion to bring the president to constitutional accountability. It would be the responsibility of the chairman of the parliament to inform the president of the date of the parliamentary session and of the obligation to provide, at the latest on the seventh day before the scheduled parliamentary session, a written response to the allegations made. He would also notify the prosecutor and his deputy indicated in the motion to bring the president to constitutional responsibility. A period of fourteen days between the appointment and the debate would allow parliamentarians to familiarize themselves with the proposal, the evidence and the committee report.

At a sitting of the parliament, the commission's report should be presented first, and then the president's response to the allegations made, either presented in person or read out by the chairman of the meeting. Subsequently, parliamentarians could ask questions to the rapporteur and to the prosecutor and his deputy indicated by the applicants, as well as to the president, provided that at this stage of the proceedings the president would not be obliged to answer. This would be followed by a debate.

The parliament would vote on the motion to indict the president for committing a constitutional tort the day after the end of the debate. Parliament would vote separately for each charge against the president. I consider two-thirds of the votes of all parliamentarians to be the optimal majority required for a resolution to be valid. The resolution of the parliament would have the features of an indictment and would list in 
its content allegations that would be supported by two thirds of parliamentarians. The remaining charges would not be covered by the indictment. Parliament could not increase the number of charges against the president as it was bound by the content of the motion.

If the president was charged, the parliament would appoint two accusers and two deputies. The parliament would thus be represented before the constitutional court by three accusers and three deputies, partly appointed by the commission, partly in pleno. Such a number would guarantee uninterrupted implementation of the proceedings, irrespective of any fortuitous reasons that prevent accusers from taking part in it. Adopting a resolution to indict the president would be tantamount to suspending them from office until the constitutional court ruled on the case. It is difficult to imagine the situation of a president accused of a constitutional tort, as a boycott of the head of state and an attempt to undermine his decisions could take place.

It would be advisable to limit - accidental or deliberate prolongation of proceedings - by specifying the duration of the proceedings. It seems that its "parliamentary stage" (until the resolution is sent to the constitutional court) should not last longer than three months. The parliament's resolution, in the form of an indictment, along with all relevant documents, would be submitted by the chairman of the parliament to the constitutional court within one week from the date of adoption of the resolution.

If none of the accusations formulated in the application obtained the required support, the proceedings on the constitutional responsibility of the president would be discontinued by the parliament. Further proceedings against the same person and on the basis of the same allegations would not be possible unless new significant circumstances came to light.

Chairman of the constitutional court, after receiving the indictment, together with the documents, it would transmit the judge-rapporteur, whose task would be to examine the indictment formally. Should the indictment show any deficiencies or errors, the chairman of parliament would have the option of rectifying them within fourteen days. If the formal deficiencies or errors are not removed, the proceedings should be discontinued at the session of the constitutional court.

The next step is the preparation by the judge-rapporteur - after reviewing the evidence - a report containing the analysis of evidence and requests for the appointment of experts, experts and witnesses, as well as for the provision of documents and information by institutions. The 
judge would have one month from the correct filing of the indictment to prepare the report and submit it to the chairman of the constitutional court. The chairman of the constitutional court would schedule the main hearing within fourteen days from the date of submitting the report by the rapporteur judge.

It should be the responsibility of the chairman of the constitutional court to summon the president and the prosecutors and their deputies to the main hearing. The president would be entitled to appoint proxies equal to or less than the number of the accusers. Moreover, all persons and institutes would be called upon to present the required documents and to appear at the constitutional court session at which the main hearing would take place.

The constitutional court would rule as a full bench in cases concerning the commission of a constitutional tort by the president. The main trial should be open to the public, and its conduct should be entrusted - due to the rank of the accused - to the president of the constitutional court.

The hearing would start with the indictment read out, then the judge-rapporteur would present the report, then the president and the prosecution would take the floor. The next stage of the hearing would be for the president and the prosecutors to answer the questions asked by the judges. This would be followed by answers from experts, experts and witnesses, and additional evidence would be presented. At the end of the main hearing, the president could take the floor again.

After the main hearing is closed, the judges of the constitutional court would hold a closed session, followed by a vote on each of the charges brought against the president. If at least one of the charges obtained the required majority, the president would be found guilty of a constitutional tort. The required majority would be two-thirds of the votes of all constitutional court judges. The possibility of submitting dissenting opinions by judges should be included. After the end of the session, the chairman of the constitutional court would publicly announce the verdict on the president's constitutional responsibility with justification.

An acquittal verdict should result in the president being reinstated in office. However, if the president was found guilty of the alleged acts, he would be dismissed ex officio. Moreover, if the constitutional court found the allegations of violation of the constitution or laws against the president very serious, it could additionally impose a penalty of deprivation of public rights for a specified period and the loss of some or all of the retirement rights due to holding the office of president. 
A constitutional court verdict on the constitutional responsibility of the president would become valid at the time of its publication, it would be final and it would not be possible to appeal it unless significant new evidence emerged. In this case, the president or an eligible applicant a (group of parliamentarians, the government or a group of citizens) would have the right to send it to the constitutional court for a reconsideration.

If at any stage of the proceedings the president resigned, this would lead to the termination of the proceedings, unless the former president had already requested the proceedings to continue. This would offer them the opportunity to clear their name.

At the time of the removal of the president from office, early elections would be managed by the authorized body. It is beyond the scope of this article to discuss the optimal solution to the question of who stands in for the president during the proceedings outlined above, as well as the period between the resignation and the swearing-in of a newly elected president.

In the presented model of the president's constitutional responsibility, efforts were made to present universal solutions that could be introduced into the constitutional system of European republics. Just as the model of non-parliamentary (judicial) constitutional review of the law has become widespread, so should - in my opinion - the model of nonparliamentary decision-making about holding constitutional accountability spread, leaving politicians - specifically the parliamentary majority - with the right of initiative in this respect.

The subject of the proceedings should be a violation of the constitution, but only a serious violation, as Italian regulations define - "an attack on the constitution", as well as a serious violation of laws concerning the state system.

Taking proceedings or refusing to initiate proceedings - given the seriousness of the case - would fall within the competence of the parliament. If the parliament initiated proceedings on the president's constitutional responsibility, the motion, together with the parliament's resolution, would be referred to the committee. Upon completion of the work, the committee would report to the Speaker of Parliament in writing. At a parliamentary session, the commission's report should be presented first, followed by the president's response to the allegations and a debate. Parliament's resolution, in the form of an indictment, along with all relevant documents, would be submitted by the speaker 
of parliament to the constitutional court. The chairman of the constitutional court, upon receipt of the indictment together with the documents, would submit them to the judge-rapporteur, whose task would be to examine the indictment. The chairman of the constitutional court would schedule the main hearing of the president and the prosecutors. After the main hearing was closed, the judges of the constitutional court would hold a closed session, followed by a vote on each of the charges brought against the president. After the end of the session, the chairman of the constitutional court would publicly announce the verdict on the president's constitutional responsibility with justification.

The considerations about the nature of the president's responsibility in contemporary European republics verify the reality. While a number of constitutions of European states introduce the constitutional responsibility of the president, none of them provides for the possibility of bringing him to political accountability, or - which is in fact the same - parliamentary responsibility.

Objections may arise from granting the authority to dismiss the president from office to the same body that brought the accusation, because in this case there is no separation of procedural tasks. This may result in the accusation of the lack of objectivity and the lack of competence of the chamber, due to the possibility dominated by the supporters or opponents of the accused president.

In order to meet the requirement of the appropriate rank and authority of the authority, the task of judging the head of state should be entrusted to an institution belonging to the supreme state organs. However, a reservation should be added that it cannot be the same institution that presented the indictment. Moreover, it should not be any of the organs of executive power which, by definition, are denied judicial competence due to their servant character.

After getting acquainted with the various regulations of the president's constitutional responsibility operating in European countries, one can come to the conclusion that the only body meeting all the requirements would be the constitutional court. Most of the states - i.e. ten out of eighteen which have included the institution of the president's constitutional responsibility in their system - have established the constitutional court as a body authorized to conduct proceedings and issue a ruling on the president's accusation of committing a constitutional tort.

The argument in favor of granting such powers to constitutional courts is their special position in the system of state organs. Members of the constitutional court are selected on the basis of their knowledge 
and experience, which guarantees professional and competent performance of their duties. Moreover, they are trusted by citizens due to their impartiality and apoliticality. Thus, it gives them an advantage in competing with the parliament in terms of their competence to adjudicate in matters related to constitutional responsibility.

The accusation that can be made of such a solution is the way in which the composition of constitutional courts is formed by decisions of parliaments, which creates the presumption that members of the tribunals represent the interests of specific political options. Practice proves, however, that this allegation is ineffective, and members of constitutional courts are characterized by high independence due to the creation of efficiently functioning mechanisms of guaranteeing independence.

\section{Bibliography}

B. Banaszak, Porównawcze prawo konstytucyjne wspótczesnych państw demokratycznych, Warszawa 2007.

E. Berselli, Tutti poreti del presidente, «Il Mulino»1992, No. 2.

R. Bin, G. Brunelli, A. Pugiotto, P. Veronesi, Il „Caso Cossiga”. Capo dello Stato che esterna o privato cittadino che offende?, Torino 2003.

I. Bokszczanin, Prezydent Republiki Włoskiej, [in:] J. Osiński (ed.), Prezydent w państwach wspótczesnych, Warszawa 2009.

P. Chrzczonowicz, Problem odpowiedzialności konstytucyjnej i karnej Prezydentów Rzeczypospolitej Polskiej i Republiki Wtoskiej, [in:] Z. Witkowski (ed.), Konstytucjonalizm włoski $i$ polski w aktualnych fazach ich przemian. Materiaty z sympozjum. Torun, 2 czerwca 2005, Torun 2005.

M. Fiorillo, Il capo dello stato. La democrazia dalla A alla Z, Roma-Bari 2002.

M. Giżyńska, Odpowiedzialność konstytucyjna głowy państwa w Republice Litewskiej (na tle kazusu Rolandasa Paksasa), [in:] A. Jamróz, S. Bożyk (eds.), Z zagadnień wspótczesnych spoteczeństw demokratycznych, Białystok 2006.

D. Górecki, R. Matonis, Odpowiedzialność konstytucyjna Prezydenta Republiki Litewskiej Rolandasa Paksasa, «Przegląd Sejmowy» 2004, No. 4.

S. Grabowska, Formy odpowiedzialności konstytucyjnej $w$ Republice Rumunii, [in:] S. Grabowska, R. Grabowski (eds.), Formy odpowiedzialności konstytucyjnej w państwach europejskich, Toruń 2010.

S. Grabowska, R. Grabowski, Odpowiedzialność prawna czy polityczna? Watpliwości w sprawie charakteru instytucji odpowiedzialności Prezydenta Republiki Rumunii, [in:] R.M. Czarny, K. Spryszak (eds.), Państwo i prawo wobec wspótczesnych wyzwań. Wspótczesne ustroje państwowe i rozwój demokracji w Polsce. Księga jubileuszowa Profesora Jerzego Jaskierni, T. II, Toruń 2012.

S. Grabowska, Referendum jako instytucja odpowiedzialności konstytucyjnej prezydenta. Analiza islandzkich regulacji, [in:] J. Ciapała, P. Mijal (eds.), Ksiega Jubileuszowa prof. Andrzeja Bałabana, Szczecin 2017. 
S. Grabowska, Udziat parlamentu $w$ postępowaniu $w$ sprawie odpowiedzialności konstytucyjnej Prezydenta Republiki Włoskiej, «Gdańskie Studia Prawnicze» 2014, T. XXXI.

$\mathrm{K}$. Ryan, A President triumphs at the polls - but is humbled by his loose tongue, «The Economist» of May $26^{\text {th }} 2007$.

W. Sokolewicz, Sąd Konstytucyjny w Rumunii, [in:] J. Trzciński (ed.), Sądy konstytucyjne w Europie. Bułgaria, Czechy. Rumunia. Stowacja, Wegry, T. 2, Warszawa 1997.

K. Witkowska-Chrzczonowicz, Formy odpowiedzialności konstytucyjnej w Republice Wtoch, [in:] S. Grabowska, R. Grabowski (eds.), Formy odpowiedzialności konstytucyjnej w państwach europejskich, Toruń 2010.

Z. Witkowski, Ustrój konstytucyjny wspótczesnych Włoch w aktualnej fazie jego przemian 1989-2004, Toruń 2004. 